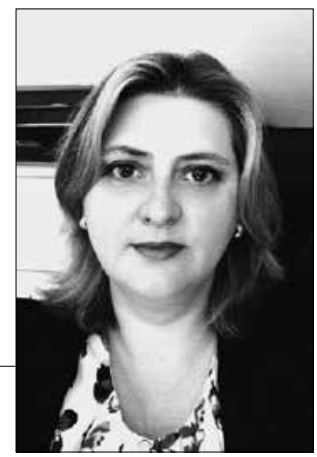

\title{
UGDOMOJO KONSULTAVIMO (KOUČINGO) METODO MOKSLO IŠTAKOS IR NAUDA ORGANIZACIJOSE
}

Scientific Sources and Benefits of Coaching Method in Organizations

\section{SUMMARY}

This article reviews the concept of coaching, its origins and its main directions At the same time, the article presents the method of coaching as one of the tools to improve employee performance, communication in the organization and promote cooperation as globalization processes and rapidly evolving modern information technologies pose various new organizational challenges. Rapidly changing business, economic, health, political, scientific and other trends also affect the formation of new societal competencies and worldviews, as well as the individual's need to reconcile personal and professional life more effectively, and for organizations to increase employee productivity and efficiency, social responsibility and changing behaviour. Not all organizations are able to adapt or learn quickly. In principle coaching provides an increasingly individual-oriented view and analysis of the individual person or team in the organization. The article also discusses the range of potential benefits of this method in organizations and possible solutions to the problems analysed by researchers.

\section{SANTRAUKA}

Šiame straipsnyje siekiama apžvelgti ugdomojo konsultavimo (koučingo) sampratą, ištakas bei esmines jo veiklos kryptis organizacijoje, pateikti ugdamojo konsultavimo metodą kaip vieną iš priemonių, padedančių gerinti darbuotojų veiklą, komunikaciją organizacijoje ir bendradarbiavimą. Globalizacijos procesai ir sparčiai tobulejjančios modernios informacijos technologijos meta organizacijoms ir pačiam darbuotojui įvairius naujus organizacinius iššūkius. Sparčiai kintantis verslas, naujausios ekonomikos, verslo, sveikatos, politikos, mokslo ir kitos tendencijos turi įtakos ir naujoms visuomenės kompetencijoms bei pasaulèžiūrai formuotis, taip pat asmens poreikiui efektyviau suderinti asmeninį ir profesinį gyvenimus, o organizacijoms siekiant didesnio darbuotojų produktyvumo ir efektyvumo, socialinės atsakomybės ir kintančios elgesio ekonomikos. 


\section{IVADAS}

Ugdomasis konsultavimas (koučingas) išpopuliarèjo XX a. 8-9 dešimt. kaip atskiras irankis ir metodas efektyviau valdyti žmogiškuosius išteklius organizacijose. Pagrindinè sąvoka "koučingas" (angl. coaching, pranc. coche) kildinama iš XVI a. vengru kalbos žodžio "kocsi“, reiškiančio vadeliojamą transporto priemonę vežimą (Moya 2008), pavadintą kaimo, kuriame pirmąkart buvo pagamintas, vardu - Kocs (Amar, Angel 2006). Ši sąvoka vartojama ir kitose pasaulio kalbose, pavyzdžiui, čekų k. - kouč, danu k. - coaching, vokiečiu k. - coaching, ispanu k. - coaching, prancūcu k. - coaching, olandu k. - coaching, norvegu k. coaching, rusu k. - коучинг ir t. t., tačiau lietuviu kalboje, deja, „koučingas“ (nors ir yra „boulingas“) sunkiai skinasi kelią kaip terminas, nors specialistu ir Valstybinès kalbos komisijos bendru pastangu apibrèžti ši terminą būta (VLKK 2013). Vietoj šio žodžio buvo ir tebèra siūlomi ¿̇vairūs atitikmenys, tokie kaip "ugdomasis (ugdantysis) vadovavimas“, ,konsultuojamasis ugdymas", "lavyba“ (VLKK 2021), tačiau šios sąvokos neišreiškia paties veiklos principo - darbo su klientu ji konsultuojant ir tuo pačiu ji ugdant bei siekiant jo sąmoningumo augimo tam tikrais asmeniniais ar profesiniais klausimais, tačiau ne vadovaujant jam ar lavinant kokius nors jo konkrečius igūdžius. Tad vengdami lietuvių kalbai ne itin priimtinos sąvokos straipsnyje vartojama "ugdomojo konsultavimo“ sąvoka, kuri iš esmès leidžia suprasti, kokios krypties konsultacija yra teikiama.

Pirmieji ugdomojo konsultavimo (koučingo) specialistai, manoma, buvo Rytu filosofai ir antikinès Graikijos atle- tai. Rytuose buvo koncentruojamasi $\mathfrak{i}$ kovos menus, kai pabréžiama ne tik fizinè, bet ir psichologinè stiprybè (pvz., pirmąsias tokias įžvalgas galime rasti Sun Tzu „Karo mene“). Šie atletai buvo laikomi pirmaisiais ugdymo specialistais - jie, kaip ir šiuolaikinių sporto sričių treneriai, padeda sportininkams pasiekti didelių asmeninių rezultatur. Taip pat manoma, kad Sokratas (469-399 m. pr. Kr.) buvo pirmasis ugdomojo konsultavimo (koučingo) specialistas, kadangi jo diskusijų metodas (majeutika) buvo grindžiamas ne ginču, o klausimais siekiant pakeisti oponento mąstymą.

$1800 \mathrm{~m}$. iškilęs susidomèjimas gamtos mokslais - biologija, geologija, fizika, kurie tuo metu buvo atskiriami nuo filosofijos studiju, - skatino domètis žmogaus kilme, jo mąstymo galia, ivvairiais pasąmonès procesais. XIX a. viduryje kilęs susidomèjimas žmogumi lèmè prielaidą atsirasti specializuotoms socialinių mokslų studijoms, kurios vèliau, apie 1900 m., iškilo kaip psichologijos mokslo pradmenys (Brock 2012).

Vèliau, jau 1830-1840 m. Oksfordo universitete ugdančiuoju (koučingo) specialistu (kouču) buvo vadinamas dèstytojas, kuris rūpinasi ir padeda studentui ruoštis egzaminams (Online Etymology Dictionary 2013). Ugdomasis konsultavimas (koučingas) tuo metu buvo suprantamas kaip tam tikras procesas, kurio metu studentas (klientas) siekia geresniu rezultatu, nei jie šiuo metu yra ar ruošiasi egzaminams ir juos sèkmingai išlaiko.

$1880 \mathrm{~m}$. ugdomojo konsultavimo (koučingo) terminas pirmąkart pavartotas sporto srityje ir iki $X X$ a. pradžios jis buvo siejamas su pergalingais sporto 
laimejjimais. Ir tik XX a. 9 dešimtmetyje jis oficialiai pripažintas ir pradètas sèkmingai plètoti organizacijose. Žymiu koučingo specialistų, pavyzdžiui, V. Brocko, D. Cluterbucko, Whitmore'o ir kt. nuomone, ugdomasis konsultavimas atsirado XX a. pabaigoje, 1980-1990 m., kartu su suaktyvejjusiu žmogiškųjų išteklių valdymu, su „minkštosios“ vadybos (angl. soft management) savybių sureikšminimu ir jų svarba organizacijoms.

Ugdomojo konsultavimo pagrindai neretai grindžiami A. Adlerio (18701937) psichologijos teorija, anot kurios, „mes visi esame priimančios būtybès, atsakingos už savo veiksmus ir elgesi"“. Jis atkreipè dèmesi $\mathfrak{i}$ žmogų pasaulyje, kuris daro itaką ir pats yra veikiamas santykių su kitais žmonėmis. Psichologo, kaip ir ugdančiojo konsultanto, pagrindinis siekis yra padèti žmonèms gyventi efektyviai ir jausti, kad jie priklauso visuomenei, kad yra jos dalis.

Analizuojant ivvairią populiariąją ir mokslinę literatūra, aiškèja, kad ugdomasis konsultavimas (koučingas) gali būti apibrèžiamas ir kaip judejjimas i prieki ir pagalba gerinant individualu žmogaus, komandos, organizacijos darbą (Downey 2008), menas skatinti veiksmus, mokytis vienas iš kito (Downey 2008); pagalba siekti geriausiu savo rezultatų (Lundin, Paul, Christensen 2003), ",atrakinti” kito potencialą siekiant maksimizuoti jo galimybes veikti (Whitmore 2002), sumažinti atotrūkị tarp ,galvoju, kad darau” ir ,darau” (Martin 2001), veikti geriausiai esant asmeninei, privačiai pagalbai, skatinti iššūkius veikti, palaikyti ir padèti augti (Donovan 2021).

Taigi ugdymo specialistas skatina vykti reikalingus teigiamus pokyčius, t. y. tokius, kurie padètų tapti geresniam per se. Kaip teigia Timas Gallwey'us (1974, lietuvių k. - 2015), kurio knyga The inner game of tennis (Vidinis teniso žaidimas) laikoma viena esminių ugdomojo konsultavimo teorijoje: „ugdymas pažadina geriausia, ką žmonès, itskaitant ir save, turi". Šioje knygoje autorius pateikè požiūrì i sporto, pritaikyto verslui, taktiką ir pavadino ją ",instruktavimu“. Tai tam tikra filosofija, analizuojanti žmogaus galimybes, igalinanti ji ir nukreipianti jo siekių link. Autorius susiejo elementus iš humanistinès psichologijos, budistų mąstymo, sporto, psichologijos ir pasąmonès programavimo idejų. Ugdomasis konsultavimas yra ilgalaikis (5-6 susitikimų) procesas, o ne vienkartinis ivvykis, nors retkarčiais taip gali nutikti, jei klientas nèra įsipareigojęs imtis pokyčių. Viso tokio konsultavimo darbo ir proceso efektyvumo kriterijus yra apsibrèžto rezultato pasiekimas.

T. Leonardas, sekdamas T. Gallwey'aus idejomis, 1988 m. sukūrè pirmuosius mokymus „Kurk savo gyvenimą“ bei įsteigè „Gyvenimo planavimo koledžą", o 1994 m. ìsteigè Tarptautinę koučingo federacija, dabar plačiai pasaulyje žinomą ICF vardu ir telkiančia daugiau nei 40 tūkst. ugdomojo konsultavimo specialistų visame pasaulyje. Nuo 1990 m. T. Leonardo idejos plito tik JAV, tačiau vèliau, pasiekus Europa, suteikè pagrindo atsirasti ivairioms ugdomojo konsultavimo organizacijoms, pavyzdžiui, 1999 m. Jungtinejje Karalystëje buvo įurta Koučingo akademija, 2000 m. - Europos koučingo institutas (O'Connor 2007) ir kt.

Everedas ir Selmanas (1989) teigia, kad ugdomojo konsultavimo specialistai, arba tuo metu dar vadinti treneriais (angl. coach - treneris), buvo pasitelkiami padèti individualiems žaidejjams didinti 
asmenini darbo našumą arba komandoms pasiekti geresni komandos darbo našumą (p. 16). Tai paskatino įvairius visuomenès veikëjus, viešu kalbų sakytojus ir aktorius, scenos atlikejus ir ypač verslininkus dirbti su ugdančiaisiais konsultantais siekiant asmeninių ir profesinių tikslų.

I. F. Stein (2003) kildina ugdomaji konsultavimą iš psichoterapijos, ugdymo, komunikacijos studiju, vadybos ir lyderystès mokslų, socialinès sistemos teoriju, suaugusiu ugdymo teoriju, holistinio mąstymo perspektyvos. Anot šios mokslininkès, kuo daugiau bus tiriamas ugdomasis konsultavimas, kuo daugiau bus praktikos, tuo stipresnis bus „,kamienas“, ant kurio augs "lapai“ - konkrečios ugdomojo konsultavimo praktikos ir patirtys. Todèl ji itin pabrěžia ugdomojo konsultavimo tyrimus, duodančius apčiuopiamos naudos organizacijoms ir irodo šio metodo realu efektyvumą.

Anot Flaherty (2010), sąvoka „ugdomasis konsultavimas“ (,koučingas“) buvo siejama su sportu, teatro ir meno profesionalais, reiške atletu, scenos atlikejjų ir studentu pagalbininką ir tik daug vèliau buvo išplètota ir i̇terpta i vadybos, lyderystès, antreprenerystės ir kitas vadybos bei gyvenimo veiklos sritis. Ugdomojo konsultavimo disciplina kaip pagrindinį iškelia klausimą kaip vienas žmogus gali padèti kitam žmogui tobulinti savo gebëjimus, atrasti naujas galimybes ir siekti kokybiško proceso tiek asmeniniame, tiek profesiniame gyvenime. Flaherty (2010) pažymi, jog toks procesas itin svarbus naujoms kartoms.

Nepaisant bandymų apibrèžti ugdomojo konsultavimo metoda, patys specialistai, dirbdami su klientais, neretai eklektiškai taiko įvairias kitas technikas iš kitų disciplinų. Pavyzdžiui, konsultantas praktikoje gali remtis intervencijomis (Block 1999; Schein 1969), "skolintis“ vadyboje esančius lyderystès stilius (Hersey, Blanchard 1969), pritaikyti organizaciju plètojimo ir organizaciju sistemų sampratos teoriją (Senge 1990), organizaciju pokyčiu valdymo principus (Argyris, Schon 1996).

Ugdomojo konsultavimo specialistai gali taikyti humanistinés psichologijos elementus (Peltier 2001; Stober, Grant 2006; Skiffington, Zeus 2003), psichodinaminę teoriją (Kilburg 2004), Adlerio principais grịstą abipusę pagarbą ir stiprybių išryškinimą (Page 2005), biheviorizmo principus (Peltier 2001), klinikinės psichologijos terminus (Hudson 1999), kognityvinę elgesio teoriją (Auerbach 2006), i s sprendimus orientuotą požiūrị (Hudson 1999; Green, Grant 2003; Cavanagh, Grant 2006; Ting, Scisco 2006), asmens raidos principus (Laske 2004; Berger 2006; Ting, Scisco 2006). Iš neurologijos (Rock 2006) ugdymo specialistai ieško paaiškinimų, kaip ir kodèl ugdomasis konsultavimas veikia (Grant 2005: 1), ir tuo pagrindžia savo veikla, ir t. t. Tad ugdomasis konsultavimas išties yra ivairialypis procesas, sudarytas ir pagricstas ịvairiomis teorijomis bei technikomis, ir vienareikšmiai jo analizuoti ar šališkai jo vertinti negalime.

Anot Granto (2005), ivairiu profesiju specialistai gali darbuotis kaip ugdantieji konsultantai. Tokios sritys gali būti verslo, vadybos, švietimo, organizaciju plètros, klinikinès psichologijos, organizaciju, sporto psichologijos, scenos menai ir sportas. Galimas daiktas, toks ivvairiu sričiu ịtraukimas į ugdomajị konsultavimą ir vice versa kelia nerimstančias diskusijas, kas išties yra ugdomasis konsul- 
tavimas, tačiau organizacijose taikomas ugdomojo konsultavimo metodas turi aiškius taikymo „rèmus“, kitaip nei vadinamasis "gyvenimo" (angl. life coaching) klausimu konsultavimas, kuris retai kada pasižymi ir moksliniu pagrịstumu. Tačiau svarbiausia ugdomojo konsultavimo metu, kad nepriklausomai nuo irankiu ir krypties, specialistai ir konsultantai laikytųsi Profesinés etikos kodekso ir vadovautųsi Tarptautinėmis ugdymo (koučingo) kompetencijomis, kurios yra patvirtintos Tarptautinès koučingo federacijos (ICF) ir vienodos visame pasaulyje, o tai leidžia užtikrinti ugdymo proceso profesionalumą ir metodo nuoseklumą.

\section{UGDOMOJO KONSULTAVIMO PROCESAS IR JO NAUDA ORGANIZACIJOMS}

Ugdomasis konsultavimas kaip procesas būna suplanuojamas organizacijoje atsižvelgiant $\mathfrak{i}$ jos poreiki. Tam, kad tokios konsultacijos įvyktu, mokslininkai iškelia tokias sąlygas, kurios leidžia užtikrinti efektyvu procesą: klientas turi norèti tobulèti ir sutinka, kad viskas yra svarstytina pateikiant ir atsakant $i$ klausimus, klientas turi tikèti ugdomojo konsultavimo metodo efektyvumu ir jo duodama nauda, klientas turi turèti konkretų suformuluotą klausimą / problemą, klientas turi pasitikèti savo konsultantu (Grant 2005).

Mokslininkų pastebima ir išskiriama nauda organizacijose, taikant ugdomaji konsultavimą galima sukurti aukšta, aiškiomis vertybėmis ir išgryninta misija paremtą organizacijos vidinę kultūrą bei sąmoningai pasirinktą jos socialinę atsakomybę (Donovan 2021). Dažnai sẻkmingos organizacijos taiko ugdomojo konsultavimo požiūrį ir jo metodą organizacijos ir jo darbuotoju proceso valdymui.

Kompaniju „Apple“ ir "Google“ specialistas, Silicio slènio aukščiausio lygio vadovu ugdantysis konsultantas Billas Campbellas teigia, kad organizacijoje itin svarbu jos veiklos ilgaamžiškumas ir aiškiai apibrèžtos vertybès. Tokio spe- cialisto i̇sitraukimas i didžiausias organizacijas ir galimybè bendradarbiauti leidžia sudèlioti organizacijos struktūrą ir tapti jos vienu svarbiausių architektu (Yarow 2003).

Atitinkamai įsitraukiant ị organizacijos procesus, svarbu tampa ne tai, kas greita ir pakeičiama, o tai, kaip organizacija gali siekti savo tikslų bendradarbiaudama su atskirų departamentų ir skyriu vadovais ir diegiant atitinkamą vidinę bendravimo ir skatinimo kultūrą. Anot B. Campbello, „,organizacijai itin svarbus lyderis. Jei tokio nèra, reikia pasamdyti geriausią vadova, kuris žinotu, kaip kurti inovacijas, ir jaustu tam aistrą. Jis / ji pats nebūtinai turi būti pats inovatyvus, tačiau turi žinoti, kaip skatinti tas inovacijas. Labai svarbu suburti komandas, o augimas lieka kaip tikslas, kuris imanomas tik siekiant inovacijų. Inovacijos ateina dèl puikių inžinierių, o ne produkto marketingo žmonių. <...> Aš ",spaudžiu“ samdant darbuotojus ir keliant ju kvalifikaciją, kuriant juos dar geresnius, „spaudžiu“ dèl inovacijų ir jų prasmès. Žmonėms labai svarbu jausti prasmę, dèl ko visa tai kuria“" (Yarow 2003).

Ugdomosios kultūros diegimas organizacijoje leidžia ne tik subalansuoti dar- 
bą tarp darbuotoju, siekti užsibrèžtų rezultatu, bet ir kuria pozityvią organizacijos atmosfera, kuri motyvuoja darbuotojus. 2014 m. Mykolo Romerio universiteto mokslininkų atliktų tyrimų pagrindu išleistoje mokslo studijoje tvirtinama, kad ugdomojo konsultavimo metodas yra suprantamas ir galimas taikyti tada, kai organizacija siekia kurti tam tikrą aukštą vidinę organizacijos kultūrą arba ja pasižymi (Raišienė 2014: 239).

Atlikę tyrimą Mykolo Romerio universiteto mokslininkai atskleide, kad dauguma Lietuvos organizaciju yra pasiruošusios diegti ugdomąją kultūrą, tačiau atitinkamai jos turètų investuoti i papildomas žinias ir atitinkamų kompetenciju formavimą bei skirti tam papildomo laiko ir finansinių išteklių. Kaip vienas pagrindinių ugdomojo konsultavimo pranašumu tyrimo metu buvo išskirta galimybẻ pažinti save ir išsikelti naujus tikslus, labiau pažinti ir suprasti darbuotojus, galimybè augti kaip asmenybėms ir auginti komunikacijos, sprendimu prièmimo kompetencijas, didinti motyvaciją ir mokytis prisiimti daugiau atsakomybès. Šalia šių galimybių ugdomasis konsultavimas pateikiamas kaip alternatyva iprastam, direktyviam vadovavimo stiliui ir kaip vienas būdų kurti aukštos vidinès kultūros organizaciją. Taikant ugdomojo konsultavimo principus buvo pabrèžiamas ir organizacijos mikroklimato pagerẻjimas, darbuotojų atvirumas naujovems, spartus pokyčiu integravimas ir palankus ju vertinimas. Mokslininkai pabrěžè, kad esant ypač nepastovioms ekonominèms sąlygoms, ugdomojo konsultavimo metodo taikymas padeda organizacijoms ne tik išlik- ti, bet ir pirmauti (Raišienè 2014; Grant 2005B; Whitmore 2002 ir kt.).

Mokslinejje literatūroje išskiriama ir pabréžiama svarba investavimo grąžos ir atsiperkamumo (ROI, angl. return on investment). Pastebima, jog investuojant $i$ organizacijos vidinių ar išorinių ugdomujų konsultantų samda, apmokymus ir metodo taikymą organizacijoje, vadinamoji investavimo grąža būna keliskart didesnè nei investuota - kaskart investavus ị savo darbuotoja grąža skaičiuojama nuo 100 iki $700 \%$, o kartais ir daugiau. Pavyzdžiui, 2001 m. Fortune 500 atlikto tyrimo duomenys atskleidè, kad investavimo grąža išauga nuo 5 iki 7 karto - ugdomojo konsultavimo metodo taikymas leido susigrą̌inti 529 proc. pajamu (Anderson 2001).

Atitinkamai pastebima, kad taikant ugdomajij konsultavimą, 23 proc. išauga efektyviai veikiančiu komandu ekonominè pridètinè vertè, 29 proc. išauga finansiniu investiciju grąžos, kai komanda turi aišku tikslą ir kompanijos tikslų krypti (Price, Tove 2017), bei 70 proc. išauga pats komandos veiklos efektyvumas (Peters, Carr 2013).

Samdant ugdomojo konsultavimo specialistą, organizacijoje dažniausiai orientuojamasi i tokius jos aspektus kaip darbo našumo didinimas, darbuotoju pasitikèjimo ir motyvacijos stoka, atitinkamo elgesio ir kultūros trūkumas organizacijoje, efektyvesnio vadovavimo siekimas, individualaus darbo gerinimas, pokyčiu prièmimo spartinimas organizacijoje, atsidavimo organizacijai trūkumas, efektyviai dirbančiu darbuotoju skaičiaus didinimas, mokymosi ir mokymo kultūros diegimas, pagalbos suteikimo derinant darbuotoju asmenini 
ir profesini gyvenimą poreikis (Scoular, Ibarra 2019).

Ugdomasis konsultavimas gali būti pasitelkiamas valdant organizacijos pokyčius, formuojant ir gerinant komandu darbą, valdant žmonių išteklius organizacijose, tobulinant tarpasmeninius, visos šeimos santykius ir gerinant bendradarbiavimo, partnerystès galimybes. Pažymètina, jog ugdomojo konsultavimo metodas tinkamas valdyti mobingo situacijas organizacijose, teisinių konsultacijų metu, viešo sektoriaus organizacijose panaudojant kaip nepiniginę motyvavimo priemonę, NVO organizacijose gerinant ir darbuotoju santykius, ir paslaugas klientams, ypač krizès centruose (pvz., Moteru krizių centre ar jaunimo organizacijose, jaunimo linijose), užimtumo tarnybose siekiant išsiaiškinti įdarbinamuju požiūrị ir galimybes dèl darbo, planuojant profesinę karjera, švietimo ir ugdymo izstaigose (pvz., darželiuose, mokyklose ugdant mokinius, administraci- jos problemoms spręsti ir pan.). Tad ugdomasis konsultavimas turi gana platu pritaikomumą.

Anot P. D. Braughton (2013), dauguma ugdomojo konsultavimo instrumentų galètų būti pateikiami mokymų metu ir tai galètu teikti didžiausią naudą organizacijoms. Ypač naudinga taikyti ugdomuosius pokalbius ir po jau ivvkusių mokymu aptarti ju nauda, igytą patirti ir galimybes pritaikyti igytą medžiagą bei žinias darbinèse situacijose (Braughton 2013). Kita vertus, M. Dixon, N. Toman ir R. Delisi (2013) naujausioje knygoje The Effortless Experience teigia, kad klientu aptarnavimo ir pardavimu sričiu specialistams labiausiai reikia ne mokymų, o būtent ugdomojo konsultavimo. Šis procesas reikalingas nuolat ir vyksta pagal užsakymą. Ugdomasis konsultavimas priklauso ir nuo ugdančiojo konsultanto, ir nuo kliento įsitraukimo, o daugiausia dèmesio skiriama tobulejjimui.

\section{IŠVADOS}

Nepaisant sunkumu, atsiradusių dèl ugdomojo konsultavimo sąvokos apibrèžimo, ši veikla suprantama kaip pagalba klientui siekti savo asmeninių ar profesinių tikslų ir gali būti taikoma įvairiose srityse: sporte, versle ar švietime. Mokslininkai išskiria įvairias kitas gretutines mokslo kryptis, tokias kaip psichologija, kognityvinę elgesio teorija, neuromoksla, vadybą pokyčių valdymą ir kt., kurių žinias pritaikius, galima ši metodą taikyti kuo plačiau. Kartu pažymètina, kad vienpusiškai ir vienareikšmiškai analizuoti ugdomojo konsultavimo negalima ir tenka remtis įvairių mokslų žiniomis. Mokslininkų pripažistama, kad ugdomojo konsultavimo efektyvumo kriterijus yra apsibrěžto rezultato pasiekimas.

Mokslininkai pripažista, kad ugdomasis konsultavimas svarbus šiuolaikinėms arba siekiančioms tokiomis būti organizacijoms, kurios pasižymi aukšta organizacijos kultūra. Toks metodo taikymas rodo ir organizacijos gebejjimą isigilinti i bendruosius, strateginius, tikslus bei kartu efektyviai valdyti žmogiškuosius išteklius skatinant juos nematerialiomis motyvavimo priemonėmis. 


\section{Literatūra}

Amar P., Angel P. 2006. Le coaching. Paris: PUF. Prieiga per internetą: https://fliphtml5.com/ xxppp/gwbr/basic

Anderson M. C. 2001. Executive Briefing: Case Study on the Return on Investment on Executive Coaching. Prieiga per internetą: http://www. empowermenttoolbox.com/MertrixSurvey.html

Braughton P. D. 2013. Using Coaching to Increase Practitioners' Skills and Knowledge for Implementing Evidence-Based Inclusive Practices. Prieiga per internetą: https://studylib.net/ doc/9203909/using-coaching-to-increase-practitioners--skills-and-know

Brock V. 2012. Acto Coaching History and Evolution. Coach Training, Development and Education. ACTO Conference, April 20.

Coaching innovation: an interview with Intuit's Bill Campbell. Prieiga per internetą: http://www. businessinsider.com/bill-campbell-twitter-201311\#ixzz3YnNc3qQy

Dixon M., Toman N., Delisi R. 2013. The Effortless Experience. Prieiga per internetą: https://innovan.do/wp-content/uploads/2015/07/INT15_ The-Effortless-Experience.pdf

Donovan G. 2021. A definition of coaching. Prieiga per internetą: http://www.evancarmichael.com/ Business-Coach/2586/A-Definition-of-Coaching. html [žiūrèta 202103 21]

Downey M. (2008). Efective coaching: Lessons from the Coaches' Coach, 2nd Edition. UK: Texere Publishing.

Raišienè A. G., Vanagas R. ir kt. Dromantaitė A. 2014. Naujas požiüris ị vadovavima: koučingo taikymo praktika Lietuvos organizacijose. Dromantaitè, A., Veiksmingos vadybos gairés: teorinés j̧žvalgos ir Lietuvos organizaciju atvejai, 2014: 239.

Evered R. D., Selman J. C. 1989. Coaching and the Art of Management. Organizational Dynamics 18: 16-32.

Flaherty J. 2010. Coaching - Evoking Excellence in Others. USA, Elsevier.

Grant A. M. 2005. Workplace, Executive and Life Coaching: An Annotated Bibliography from the Behavioural Science Literature. Unpublished paper, Coaching Psychology Unit, University of Sydney, Australia. Prieiga per internetą: https:// groups.psychology.org.au/Assets/Files/article_ Annotated_biblio.pdf

Yarow J. 2003. Steve Jobs', CEO Coach' Gave A One Hour Talk About What Makes A Great Company. Prieiga per internetą: http://www.busines- sinsider.com/video-of-bill-campbell-talkingabout-the-tech-industry-2013-4\#ixzz3YgRUTUqj

Interviu su Leda Turai Petrauskiene (MCC): galima koučingo nemėgti ar ji kritikuoti, bet vargu ar sustabdysime jo evoliuciją. Prieiga per internetą: http://coachingblog.lt/tag/interviu-apie-koucinga [žiūrèta 202106 30]

Intuit CEO Converstations with Brad Smith and Bill Campbell. Prieiga per internetą: http://www. businessinsider.com/video-of-bill-campbell-talking-about-the-tech-industry-2013-4\#ixzz3Yg RUTUqj

Kuo keičiamas kaučingas (koučingas) (angl. coaching)? Prieiga per internetą: http://www.vlkk. lt/konsultacijos/6722-kaucingas-koucingas-kauceris [žiūrèta 202108 16]

Lundin S., Paul H., Christensen J. 2003. Fish Hodder Mobius.

Martin C. 2001. The Life Coaching Handbook. Crown House Publishing Ltd.

Moya L. 2008. Un recorrido por las raíces filosóficas del coaching. Materiabiz. Prieiga per internetą: http://www.fernandoflores.cl/node/2237

O'Connor L. 2007. How Coaching Works: The essential guide to the history and practice of effective coaching. Prieiga per internetą: http:// www.adam-europe.eu/prj/3761/prd/7/1/Handbook\%20Lithuanian.pdf

Pasitarimas dẻl anglų kalbos termino „koučingas“ lietuviško atitikmens. Prieiga per internetą: http://www.vlkk.lt/naujienos/ivykiu-kronika/ pasitarimas-del-anglu-k-termino-coaching-lietuvisko-atitikmens [žiūrèta: 202108 16]

Peters J., Carr C. (2013). Team effectiveness and Team Coaching Literature review. Coaching: An International Journal of Theory, Reserach and Practice 6 (2): 116-136.

Price C., Tove S. 2017. Accelerating Perfomance: How Organizations can mobilize, Execute and Transform with Agility. Willey.

Schor J. 2011. Work Less, Live More. Prieiga per internetą: http://www.yesmagazine.org/issues/ new-livelihoods/less-work-more-living

Scoular A., Ibarra H. 2019. Leader as a coach: How unleash innovation, energy and commitment. Prieiga per internetą: https://hbr.org/2019/11/ the-leader-as-coach

Stein I. F. 2003. November 12.

Whitmore J. 2002. Coaching for Performance. 3rd Edition. London. 